\title{
Patterns of infective sero positivity among blood donors in a rural Medical College Regional Blood Transfusion centre: A retrospective study
}

\author{
Dhar $G,{ }^{1}$ Sarkar AP, ${ }^{2}$ Sen $S,{ }^{3}$ Ghosh $S,{ }^{3}$ Mukhopadhyay BB,${ }^{4}$ Ghosh $T^{5}$ \\ ${ }^{1}$ Dept of Community medicine, CNMC, Kolkata, India, ${ }^{2}$ Dept of Community medicine, BMC, Burdwan, West Bengal, India, \\ ${ }^{3}$ Dept of Pathology, CNMC, Kolkata, India, ${ }^{4}$ Dept of Community Medicine, K.P.C Medical College, Kolkata, India, ${ }^{5}$ h D \\ Scholar in Burdwan university, Burdwan, West Bengal, India
}

\author{
*Corresponding Author: \\ Dr. Tapan Kumar Ghosh \\ 40, Kotalhat \\ Burdwan-2, Burdwan \\ PIN - 713102 \\ Email: ghosh.drtapan@gmail.com
}

\section{Citation}

Dhar G, Sarkar AP, Sen S, Ghosh S, Mukhopadhyay BB, Ghosh TK. Patterns of infective sero positivity among blood donors in a rural Medical College Regional Blood Transfusion centre: A retrospective study. Nepal Journal of Medical Sciences 2013;2(1):3-8.

\section{Background:}

In spite of history taking \& screening Transfusion Transmitted Infections (TTI) is still burden for safe transfusion and responsible for hazards of Blood Transfusion. Blood is a

\section{ABSTRACT}

Background: Transfusion-transmitted infections (TTI) is still burden that continue to be a threat to safe transfusion practices of blood \& components and one of the major problem in delayed transfusion hazards. In the present study prevalence and patterns of co-infections among voluntary and replacement donors were analyzed.

Methods: This is descriptive study. Blood collected over a 6-year period were studied for the type of donation (voluntary or replacement), number of seroreactive cases and the number, type and distribution of coinfections among different type of donors.

Results: Out of 127995 units of collected blood, 106755 (83.40\%) were voluntary and $21240(16.60 \%)$ replacement donors of them 1463 were seroreactive. Out of 1463 seroreactive cases (1.14\%) 128(0.10\%), 137(0.11\%),1025(0.8\%) \& 173(0.13\%) were HIV, HCV, HBsAg (Hepatitis B surface antigen) \& VDRL (Venereal Diseases Research Laboratory) respectively. $30(0.02 \%)$ cases of seropositive samples showed more than one seroreactive reactions which were collected $14(0.06 \%)$ from replacement donors and $16(0.01 \%)$ samples from voluntary donors. Only 2 samples $(0.001 \%)$ of repeat donors show seropositivity.

Conclusion: Possibilities of transfusion transmitted infections were more with replacement blood donors in comparison to voluntary blood donors. Repeat donors were safer than first time donors. Though the incidence was less, chances of multiple infections were still problems to the recipients. Proper history taking, screening and encouragement of blood donation would definitely reduce the chances of transfusion transmitted infection.

Keywords: Transfusion-transmitted infections; blood donors; seropositivity

life saving resource; still it can be the one of the source of infective diseases if there remain any lacunae in screening of blood during processing. Several factors play a role to detect TTI .In spite of meticulous testing one can not detect the infections in "Window Phase". If we look back the 
incidence of TTI would be more .In spite of technological advancements, the problems of 'window period', falsenegative results, prevalence of asymptomatic carriers, genetic variability in viral strains and technical errors to be considered. ${ }^{1}$

Hepatitis B is one of the common TTI. In most of the blood banks the diagnosis of HBV infection is based on the presence of Hepatitis B Surface Antigen in the Blood stream which does not confirm the absence of HBV infection. The occult $\mathrm{HBV}$ infection can only be diagnosed by $\mathrm{HBc}$ and HBV DNA. Many workers had shown a significant numbers of HBsAg negative blood donors were anti $\mathrm{HBc}$ positive and exposed to HBV infection. These donors are potential for transmitting HBV contaminated blood. ${ }^{2}$

Hepatitis $\mathrm{C}$ virus (HCV) is another important cause of post transfusion non-Anon $\mathrm{B}$ hepatitis and 200 million individuals had chronic HCV infection. The global seroprevalance of HCV among blood donors varies from $0.4-19.2 \%{ }^{3}$

Some literatures showed $0.81 \%$ HIV Positivity ${ }^{4}$ and presence of co- infection TTI among blood donors. Currently safe blood transfusion is ensured by careful donor's selection and mandatory screening for TTI. In spite of all precautions, transmission of HIV via blood and components transfusion is still present. This is mostly due to collection of blood during window phase .5

There are many studies on the prevalence of TTI in blood donors. ${ }^{6-8}$ Less number of data showed presence of coinfection with more than one TTI. ${ }^{6-9}$ In the present study we analyzed the patterns of infections among the blood donors and the recipients including multireceipients (thalassaemia), in a rural medical college and hospital blood bank in our region covering about average distance of $30 \mathrm{~km}$ around the centre over a period of 6 years. TTI continue to be problems in many part of the world as well India and the multitransfused patients of Thalassaemia major are particularly at increased risk of TTI. ${ }^{10}$ The aim of this study was to find out the incidence of seropositivity of TTI among the blood donors (voluntary + replacement) and increase the number of donors for safe blood.

\section{Methods:}

The present study was conducted at the Department of Pathology, Burdwan Medical College and Hospital, Burdwan over a period of 6 years (2006-2011) taking all blood collected during this period. The donors were either voluntary (Camp) or replacement donors (relatives or friends of patients in the blood bank). All samples were screened for hepatitis B surface antigen (HBsAg; Hepalisa, J.Mitra ELISA of SPAN), anti-human immunodeficiency virus antibodies (HIV Ab;HIV 3rd generation kit for detection of antibodies to HIV1 and HIV2, J. Mitra \& S.D. lab), antihepatitis $\mathrm{C}$ virus antibodies (HCV Ab; Micro ELISA 3rd generation, J. Mitra \& SD Lab ) and Venereal Diseases Research Laboratory (VDRL) reactivity (Carbogen kit, Tulip Diagnostics as well as RPR Span ). The multi transfused patients of Thalassaemia major were tested for TTI at an interval of 6 months. The total number of seroreactive cases and their distribution were noted. Cross checking was done by calling the donors through post or over telephone. The donors with more than one seroreactivity were noted and were identified as co- infection. All statistical analysis were done using SPSS version 17.

\section{Results:}

Out of total 127995 units of collected blood 106755 (83.40\%) were from voluntary and $21240(16.60 \%)$ from replacement donors .Total collection showed $75 \%$ were rural donor and $25 \%$ urban donors. Of the Voluntary donors $91.70 \%$ were male $8.30 \%$ were female (Table-I). Among replacement donors $97.89 \%$ were male and $2.11 \%$ were female. This study showed increased trend of Voluntary blood donation (13764 in 2006 to 21631 in 2011) and increased numbers of Voluntary blood donation camp [241(2006) to 353 (2011)] (Table -1 and Chart -I ).

Table IA Year wise collection of Blood(Voluntary \& Replacement) for the period 2006-2011

\begin{tabular}{lccccccc}
\hline & 2006 & 2007 & 2008 & 2009 & 2010 & 2011 & Total \\
\hline $\begin{array}{l}\text { Total } \\
\text { collection }\end{array}$ & 17283 & 17713 & 19628 & 21177 & 24165 & 28029 & 127995 \\
$\begin{array}{l}\text { Voluntary } \\
\text { collection }\end{array}$ & 13764 & 14921 & 18375 & 18689 & 19375 & 21631 & $\begin{array}{c}106755 \\
(83.40 \%)\end{array}$ \\
$\begin{array}{l}\text { Replacement } \\
\text { collection }\end{array}$ & 3519 & 2792 & 1253 & 2488 & 4790 & 6398 & $\begin{array}{c}21240 \\
(16.6 \%)\end{array}$ \\
\hline
\end{tabular}

Table IB Year wise Voluntary collection of blood through camp according to sex for the period 2006-2011

\begin{tabular}{lccccccc}
\hline & 2006 & 2007 & 2008 & 2009 & 2010 & 2011 & Total \\
\hline $\begin{array}{l}\text { Voluntary } \\
\text { male }\end{array}$ & 12364 & 13360 & 17791 & 16793 & 17340 & 19824 & $\begin{array}{c}97472 \\
(91.30 \%)\end{array}$ \\
$\begin{array}{l}\text { Voluntary } \\
\text { female }\end{array}$ & 1400 & 1561 & 584 & 1896 & 2035 & 1807 & $\begin{array}{c}9283 \\
(8.70 \%)\end{array}$ \\
$\begin{array}{l}\text { No. of } \\
\text { Camp }\end{array}$ & 241 & 268 & 268 & 283 & 324 & 353 & \\
\hline
\end{tabular}


Original Article | Dhar G et al. Transfusion transmitted infection: a burden of blood transfusion

Table IC Year wise replacement collection of blood according to sex for 2006-2011.

\begin{tabular}{lccccccc}
\hline & 2006 & 2007 & 2008 & 2009 & 2010 & 2011 & Total \\
\hline $\begin{array}{l}\text { Replacement } \\
\text { male }\end{array}$ & 3477 & 2742 & 1200 & 2424 & 4678 & 6271 & $\begin{array}{c}20792 \\
(97.89 \%)\end{array}$ \\
$\begin{array}{l}\text { Replacement } \\
\text { female }\end{array}$ & 42 & 50 & 53 & 64 & 112 & 127 & $\begin{array}{c}448 \\
(2.11 \%)\end{array}$ \\
Camp & 241 & 268 & 268 & 283 & 324 & 353 & \\
\hline
\end{tabular}

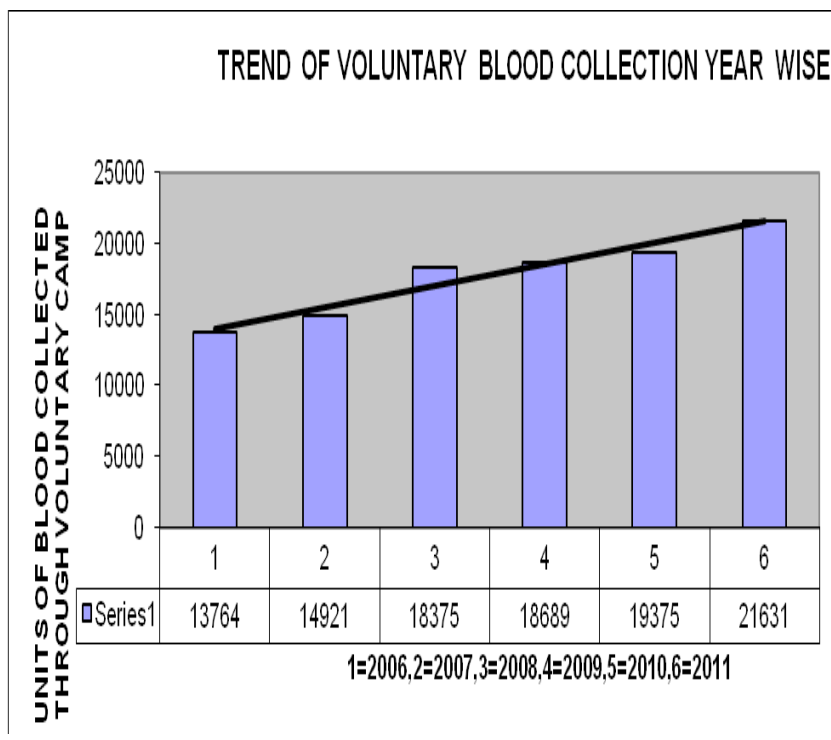

Chart-I : Showing increased trend of voluntary blood donation.

Out of total 127995 blood donors (Voluntary +Replacement) 1463(1.14\%) were seroreactive and incidence of HIV, HCV, HBsAg, VDRL reactivity were 128(0.10\%), 137(0.11\%), $1025(0.80 \%), 173(013 \%)$ respectively, which indicates highest incidence of $\mathrm{HbsAg}$ infection (72.3\%, 8 times more than that of HIV reactivity). The seropositivity of the voluntary \& replacement donors were 1166 (1.09\%) \& $297(1.39 \%)$ respectively (Table -2$)$ which indicates higher seropositivity among replacement donors. Out of 1463 sero positive donors $30(2.05 \%)$ had co-infection (more than one infection) and showed 16(1.37\%) were voluntary donors \& 14 were replacement donors (4.47\%). VDRL \& HIV confections were observed among 6(0.41\%) donors \& VDRL, HIV \& HBsAg co infections in 1 donor (0.06\%). HBsAg \&HIV, HIV with HCV, HIV with HCV \& HbsAg, HbsAg \&VDRL, HCV with VDRL, HbsAg and $\mathrm{HCV}$ confections were $7(0.47 \%), 2$ donors $(0.17 \%), 3$ donors $(0.21 \%), 6(0.41 \%), 2(0.13 \%)$ and 3 donors $(0.21 \%)$ respectively.
Table- 2A Year wise HIV\&HCVpositivity of Voluntary donors for the period 2006-2011

\begin{tabular}{lcccccccc}
\hline & 2006 & 2007 & 2008 & 2009 & 2010 & 2011 & Total & $\%$ \\
\hline $\begin{array}{l}\text { Voluntary } \\
\text { collection }\end{array}$ & 13764 & 14921 & 18375 & 18689 & 19375 & 21631 & 106755 & 83.40 \\
$\begin{array}{l}\text { Seropositivity } \\
\text { HIV }\end{array}$ & 13 & 16 & 17 & 18 & 11 & 10 & 85 & 0.08 \\
$\begin{array}{l}\text { Seropositivity } \\
\text { HCV }\end{array}$ & 17 & 20 & 22 & 19 & 16 & 26 & 120 & 0.11 \\
\hline
\end{tabular}

Table2B Year wise HBsAg \& VDRLpositivity of Voluntary donors for the period 2006-2011

\begin{tabular}{lcccccccc}
\hline & 2006 & 2007 & 2008 & 2009 & 2010 & 2011 & Total & $\%$ \\
\hline $\begin{array}{l}\text { Voluntary } \\
\text { collection }\end{array}$ & 13764 & 14921 & 18375 & 18689 & 19375 & 21631 & 106755 & 83.40 \\
$\begin{array}{l}\text { Seropositivity } \\
\text { HBsAg }\end{array}$ & 106 & 109 & 130 & 121 & 173 & 162 & 801 & 0.75 \\
$\begin{array}{l}\text { Seropositivity } \\
\text { VDRL }\end{array}$ & 18 & 28 & 22 & 25 & 28 & 39 & 160 & 0.15 \\
\hline
\end{tabular}

Table 2C Year wise HIV\&HCVpositivity of Replacement donors for the period 2006-2011

\begin{tabular}{lcccccccc}
\hline & 2006 & 2007 & 2008 & 2009 & 2010 & 2011 & Total & $\%$ \\
\hline $\begin{array}{l}\text { Replacement } \\
\text { donors }\end{array}$ & 3519 & 2792 & 1253 & 2488 & 4790 & 6398 & 21240 & 16.6 \\
$\begin{array}{l}\text { Seropositivity } \\
\text { HIV }\end{array}$ & 8 & 7 & 5 & 6 & 8 & 9 & 43 & 0.2 \\
$\begin{array}{l}\text { Seropositivity } \\
\text { HCV }\end{array}$ & 3 & 3 & 2 & 3 & 4 & 5 & 20 & 0.09 \\
\hline
\end{tabular}

Table 2D Year wise HBsAg \& VDRLpositivity of Replacement donors for the period 2006-2011

$2006 \quad 2007 \quad 2008 \quad 20092010 \quad 2011 \quad$ Total $\%$

\begin{tabular}{lcccccccc}
$\begin{array}{l}\text { Replacement } \\
\text { donors }\end{array}$ & 3519 & 2792 & 1253 & 2488 & 4790 & 6398 & 21240 & 16.6 \\
$\begin{array}{l}\text { Seropositivity } \\
\text { HBsAg }\end{array}$ & 38 & 30 & 15 & 23 & 50 & 65 & 221 & 1.04 \\
$\begin{array}{l}\text { Seropositivity } \\
\text { VDRL }\end{array}$ & 2 & 2 & 1 & 4 & 3 & 1 & 13 & 0.06 \\
\hline
\end{tabular}


Table 2E Year wise total Seropositivity of Voluntary \& Replacement donors

200620072008200920102011 Total \%

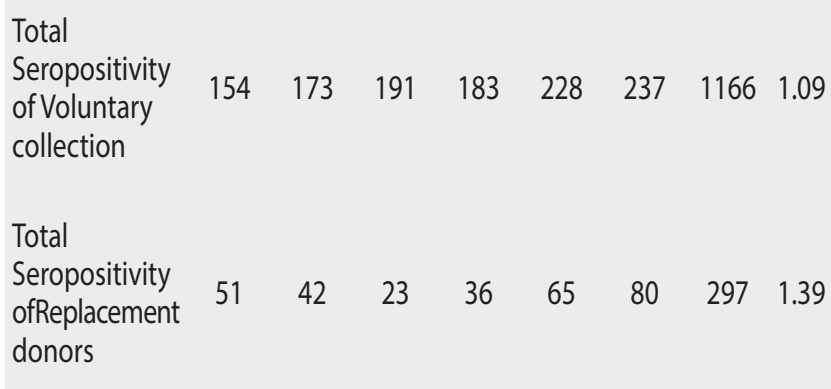

Out of total donors only 13 female $(0.01 \%)$ were seroreactive and none had co infection.

The age incidence of seropositive donors ranged from 19 to 50 years where as about $80 \%$ donors with co infection were 26 to 33 years.

Out of total 127995 collected blood 1645(1.28\%) blood were discarded, of which $1463(88.94 \%)$ were due to seropositivity and $182(11.06 \%)$ were due to other causes include hemolysis, less collection, damage to the bags during transportation and date expiry etc. 126350 units of blood were issued for transfusion. 9 multitransfused recipients were found seropositive and 7 of them were Thalssaemic. All of them were seronegaive before transfusion.

The incidence of co infection reduced dramatically from 2009. No donors were detected with co- infection in $2010 \&$ 2011 .

\section{Discussion:}

In spite of screening, TTIs continue to be burden to safe blood transfusion practices. With every unit of blood, there is $1 \%$ chance of a transfusion related problem including TTIs. ${ }^{8}$ Professional donors and donors with high risk behavior such as drug addict, homosexual, commercial sex workers carry more risk of TTI positivity. ${ }^{11}$

Transfusion of blood \& blood components are life saving measures of innumerable of patients worldwide. On the contrary blood and blood components are one the important route for transmission of TTI. In developing country absolute safe transfusion is far away which need awareness, education and improved technology for attaining zero level of Transfusion acquired infection.

In our study there were no professional donors and the blood was collected from 106755 (83.40\%) voluntary donors which is nearer to the target of NACP III (90\%) \&.21240
(16.60\%) from replacement donors.

The present study showed the seropositivity of replacement donors higher than voluntary donors $(p=0.02)$. The replacement donors were usually friends or relatives of the recipients. Sometimes replacement donors due to social factors may conceal their high risk activities to their relatives. In the present study it was observed the seroreactivity was higher in replacement donors $(1.39 \%)$ than voluntary donors $(1.09 \%)$ The concealment of Medical history and life style are the important causes of seropositivity among the voluntary and replacement donors. Higher seropositivity was observed in replacement donors in this study.

Difference in infection rates between voluntary and replacement donors have been observed in many earlier studies (Table-3). ${ }^{14-16}$ Family donors cannot be included amongst voluntary-non-remunerated blood donors as they have a higher rate of TTIs. ${ }^{17}$

\section{Table-3A Prevalence of transfusion - transmissible infection in different studies from India}

\begin{tabular}{|c|c|c|c|c|c|}
\hline $\begin{array}{l}\text { Study } \\
\text { duration }\end{array}$ & $\begin{array}{c}\text { Singh et al } \\
1997-99\end{array}$ & $\begin{array}{c}\text { Garg et al } \\
1994-98\end{array}$ & $\begin{array}{c}\text { Sharma } \\
\text { et al } \\
1997-2002\end{array}$ & $\begin{array}{c}\text { Gangadeep } \\
\text { et al } \\
2001-2005\end{array}$ & $\begin{array}{l}\text { Presentstudy } \\
2006-2011\end{array}$ \\
\hline \multirow{2}{*}{ HIV } & $\begin{array}{c}\text { Voluntary- } \\
0.8\end{array}$ & $\begin{array}{c}\text { Voluntary- } \\
0.4\end{array}$ & $\begin{array}{c}\text { Voluntary- } \\
0.45\end{array}$ & $\begin{array}{c}\text { Voluntary- } \\
0.15\end{array}$ & $\begin{array}{c}\text { Voluntary- } \\
0.08\end{array}$ \\
\hline & $\begin{array}{c}\text { Replacement- } \\
0.8\end{array}$ & $\begin{array}{c}\text { Replacement- } \\
0.2\end{array}$ & $\begin{array}{c}\text { Replacement- } \\
0.32\end{array}$ & $\begin{array}{c}\text { - Replacement- } \\
0.44\end{array}$ & $\begin{array}{c}\text { Replacement- } \\
0.2\end{array}$ \\
\hline \multirow{2}{*}{$\mathrm{HBsAg}$} & $\begin{array}{c}\text { Voluntary- } \\
1.9\end{array}$ & $\begin{array}{c}\text { Voluntary- } \\
3.5\end{array}$ & $\begin{array}{c}\text { Voluntary- } \\
1.26\end{array}$ & $\begin{array}{c}\text { Voluntary- } \\
0.65\end{array}$ & $\begin{array}{c}\text { Voluntary- } \\
0.75\end{array}$ \\
\hline & $\begin{array}{c}\text { Replacement- } \\
1.2\end{array}$ & $\begin{array}{c}\text { Replacement- } \\
2.6\end{array}$ & $\begin{array}{c}\text { Replacement- } \\
0.91\end{array}$ & $\begin{array}{c}\text { - Replacement- } \\
1.07\end{array}$ & $\begin{array}{c}\text { Replacement- } \\
1.04\end{array}$ \\
\hline
\end{tabular}

Table 3B Prevalence of transfusion - transmissible infection in different studies from India

\begin{tabular}{|c|c|c|c|c|c|}
\hline $\begin{array}{l}\text { Study } \\
\text { duration }\end{array}$ & $\begin{array}{c}\text { Singh et al } \\
\text { 1997-99 }\end{array}$ & $\begin{array}{c}\text { Garg et al } \\
1994-98\end{array}$ & $\begin{array}{c}\text { Sharma et al } \\
1997-2002\end{array}$ & $\begin{array}{c}\text { Gangadeep } \\
\text { et al } \\
2001-2005\end{array}$ & $\begin{array}{c}\text { Present study } \\
2006-2011\end{array}$ \\
\hline \multirow{2}{*}{$\mathrm{HCV}$} & $\begin{array}{c}\text { Voluntary- } \\
3.0\end{array}$ & $\begin{array}{c}\text { Voluntary- } \\
0.23\end{array}$ & $\begin{array}{c}\text { Voluntary- } \\
0.52\end{array}$ & $\begin{array}{c}\text { Voluntary- } \\
0.3\end{array}$ & $\begin{array}{c}\text { Voluntary- } \\
0.11\end{array}$ \\
\hline & $\begin{array}{c}\text { Replacement- } \\
1.3\end{array}$ & $\begin{array}{c}\text { Replacement- } \\
0.13\end{array}$ & $\begin{array}{c}\text { Replacement- } \\
0.23\end{array}$ & $\begin{array}{c}\text { Replacement- } \\
0.5\end{array}$ & $\begin{array}{c}\text { Replacement- } \\
0.09\end{array}$ \\
\hline \multirow[t]{2}{*}{ VDRL } & & Voluntary-- & $\begin{array}{c}\text { Voluntary- } \\
0.52\end{array}$ & $\begin{array}{c}\text { Voluntary- } \\
0.19\end{array}$ & $\begin{array}{c}\text { Voluntary- } \\
0.15\end{array}$ \\
\hline & Replacement- & Replacement-- & $\begin{array}{c}\text { Replacement- } \\
0.26\end{array}$ & $\begin{array}{c}\text { Replacement- } \\
0.48\end{array}$ & $\begin{array}{c}\text { Replacement- } \\
0.06\end{array}$ \\
\hline
\end{tabular}


Table 3C Prevalence of transfusion - transmissible infection in different studies from India

\begin{tabular}{lcccccccc}
\hline \multicolumn{1}{c}{$\begin{array}{c}\text { Study, } \\
\text { Duration }\end{array}$} & $\begin{array}{c}\text { HIV+ } \\
\text { HBsAg }\end{array}$ & $\begin{array}{c}\text { HIV+ } \\
\text { HCV }\end{array}$ & $\begin{array}{c}\text { HIV+ } \\
\text { VDRL }\end{array}$ & $\begin{array}{c}\mathrm{HIV+} \\
\mathrm{HBsAg}+ \\
\mathrm{HCV}\end{array}$ & $\begin{array}{c}\mathrm{HBsAg}+ \\
\text { VDRL }\end{array}$ & $\begin{array}{c}\mathrm{HCV}+ \\
\text { VDRL }\end{array}$ & $\begin{array}{c}\mathrm{HBsAg}+ \\
\mathrm{HCV}\end{array}$ & $\begin{array}{c}\mathrm{HIV+} \\
\mathrm{HBsAg}+ \\
\mathrm{VDRL}\end{array}$ \\
\hline $\begin{array}{l}\text { Gagandeep } \\
\text { Kaur etall } \\
2001-2005\end{array}$ & $22.7 \%$ & $4.5 \%$ & $18.25 \%$ & - & $22.7 \%$ & $18.25 \%$ & $9.1 \%$ & $4.5 \%$ \\
$\begin{array}{l}\text { Our study } \\
2006-2011\end{array}$ & $23.33 \%$ & $6.7 \%$ & $20 \%$ & $10 \%$ & $20 \%$ & $6.7 \%$ & $10 \%$ & $3.33 \%$ \\
\hline
\end{tabular}

In the present study 1463 donors were sero reactive showing a gradual tendency of declining seroreactivity (Chart-II).The co infection is statistically higher in replacement donors $(\mathrm{p}<$ $0.001)$ though the rate of co infection is less in our country. Gangadeep Kaur et al (2010) showed co infection is higher in replacement donors than voluntary donors $(\mathrm{P}<0.005)$ and similar to other studies (Table - 4).

Table -4 Comparison of prevalence of co- infection with other study

\begin{tabular}{lcccccccc}
\hline $\begin{array}{c}\text { Study, } \\
\text { Duration }\end{array}$ & $\begin{array}{c}\mathrm{HIV+} \\
\mathrm{HBsAg}\end{array}$ & $\begin{array}{c}\mathrm{HIV+} \\
\mathrm{HCV}\end{array}$ & $\begin{array}{c}\mathrm{HIV+}+ \\
\text { VDRL }\end{array}$ & $\begin{array}{c}\mathrm{HIV+} \\
\mathrm{HBsAg}+ \\
\mathrm{HCV}\end{array}$ & $\begin{array}{c}\mathrm{HBsAg}+ \\
\text { VDRL }\end{array}$ & $\begin{array}{c}\mathrm{HCV}+ \\
\text { VDRL }\end{array}$ & $\begin{array}{c}\mathrm{HBsAg}+ \\
\mathrm{HCV}\end{array}$ & $\begin{array}{c}\mathrm{HIV+} \\
\mathrm{HBsAg}+ \\
\text { VDRL }\end{array}$ \\
\hline $\begin{array}{l}\text { Gagandeep } \\
\begin{array}{l}\text { Kaur etall } \\
2001-2005\end{array}\end{array}$ & $22.7 \%$ & $4.5 \%$ & $18.25 \%$ & - & $22.7 \%$ & $18.25 \%$ & $9.1 \%$ & $4.5 \%$ \\
$\begin{array}{l}\text { Our study } \\
2006-2011\end{array}$ & $23.33 \%$ & $6.7 \%$ & $20 \%$ & $10 \%$ & $20 \%$ & $6.7 \%$ & $10 \%$ & $3.33 \%$ \\
\hline
\end{tabular}

Our study showed $66.66 \%$ co infection with HBsAg and $63.33 \%$ with HIV and 50\% had VDRL co infection. Most common co infection was HIV\& HBsAg (23.33\%) followed by HIV\& VDRL (20\%) and HBsAg\& VDRL (20\%) and $93.33 \%$ donors had co infection either with HBsAg or HIV.

Post transfusion infections occurred in 9 recipients $(0.007 \%)$ and mostly were Thalssaemic $(77.77 \%)$ and all were multitransfused. The TTI from screened blood depends on various factors like the safety of donor population, sensitivity of the screening tests used \& numbers of test performed window-period donations, and other reasons such as mutant strains. ${ }^{20}$

Roopam Jain et al in their study showed that out of 96 multitransfused Thalssaemic patients, 24 (25\%) were reactive for anti-HCV. The seroreactivity of males were significantly higher than females $(p<0.0001)$ No female donor showed co infection.

India has one of the largest pools of hepatitis B-infected patients $^{12,13}$ and of all seroreactive donors $\mathrm{HBV}$ is more common $(0.8 \%)$.
Chronic hepatitis B virus (HBV) infection remains a major public health problem worldwide with more than 300 million chronic carriers. ${ }^{14}$ The course of HBV infection depends on several factors that can influence the immune system, including age at infection and host genetic factors, and genetic variability of the virus influencing the expression of the viral antigens. ${ }^{18}$ Proper screening of HBV can be done to prevent transfusion-transmitted hepatitis B virus (HBV) by using progressively more sensitive HBsAg assays.

Nucleic acid amplification testing (NAT) for HCV and HIV infection had been successfully introduced to screen donors in many developed countries but the cost- effective ness to be considered in our country. ${ }^{19}$

HIV reactor among blood donors in the present study was $0.10 \%$ and had co infection $63.33 \%$. According to the action plan of NACO all the HIV reactive blood donors should be notified of their status. In the developing countries like India confirmatory tests using Nucleic acid amplification technique (NAT) on HIV seroreactive blood is not feasible.

In India seroprevalance of $\mathrm{HCV}$ varies $0.12-4 \%{ }^{21}$ which varies geographically.

Based on the results we feel that to reduce the risk of these infections blood should be accepted from voluntary donors $\&$ repeat voluntary donor. Donor selection and screening procedures must be strictly followed for the blood safety. Voluntary blood donation has to be made a part of healthy lifestyle, proper health education to be given to public about the benefits of voluntary blood donation \& proper assurance to be given to all donors regarding the life style.

\section{Conclusion:}

To wipe of scarcity of blood and ensure availability of safe quality blood \& component round the clock and throughout the year the transfusion service must necessarily be supported by voluntary blood donors.

Consequently, the recruitment of voluntary donors becomes one the most important aspects of blood transfusion services. Thus, healthy, responsive and motivated voluntary blood donors are the back-bone of the transfusion service.

Blood is a life saving agent but blood transfusion can be responsible of life threatening infections to the recipient if pre transfusion screening tests are not done properly.

Presently the safety of blood for transfusion is maintained by careful selection of voluntary donors and performing the mandatory screening for transfusion transmissible infections (TTI) as meticulously as possible. 


\section{References:}

1. Singh B, Kataria SP, Gupta R. Infectious markers in blood donors of East Delhi; Prevalence and trends. Indian J Pathol Microbiol 2004;47:477-9.

2. Bhattacharya $P$, Chandra PK, Dutta S, et al. Significant increase in $\mathrm{HBV}, \mathrm{HCV}, \mathrm{HIV}$ and Syphilis infections among blood donors in West Bengal, Eastern India 20042005 : Exploratory screening reveals high frequency of occult HBV infection. World J Gastroenterol 2007; 13:3730-3.

3. Thakral B, Marwaha N, Chawla YK, et al Prevalence \& Significance of hepatitis C virus (HCV) Seropositivity in blood donors. Indian J Med Res 2006;124:431-8.

4. Sonth SB, Solabannavar SS, Baragundi MC, et al The prevalence of HIV-2 seropositivity in blood donors. J Clin Diagn Res 2010;4:3091-4.

5. Kumar ISC, Babu KVS, Yashovardhan A, et al. HIV seropositivity and its ethical implications for blood donors in a tertiary care hospital of Andhra Pradesh. J Clin Sci Res 2012;1:8-14.

6. Mathai J, Sulochana PV, Satyabhama S, et al. Profile of transfusion transmissible infections and associated risk factors among blood donors of Kerala. Indian J Pathol Microbiol 2002;45:319-22.

7. Singh B, Verma M, Kotru M, et al Seropositivity in blood donors of Delhi. Indian J Med Res 2005;122:234-6.

8. Widman F K(ed)(1985)Technical manual. American Association of Blood Banks,Arlington, pp325-344.

9. Nanu A, Sharma SP, Chatterjee K, et al Markers for transfusion-transmissible infections in north Indian voluntary and replacement blood donors: Prevalence and trends 1989-1996. Vox Sang 1997;73:70-3.

10. Prakash JVJ, Vachhani H, Sheikh SS, et al.Blood Transfusion Transmitted Infections in Multiple Blood Transfused Patients of Beta Thalassaemia Indian J Hematol Blood Transfus 2011;27:65-9.

11. Kaur G, Basu S, Kaur R, et al. Patterns of infections among blood donors in a tertiary care centre: A restropective study. Natl Med J India 2010;23:1479.

12. Tandon BN, Acharya SK, Tandon A. Epidemiology of hepatitis B virus infection in India. Gut 1996;389:S56-9.

13. Vivekanandan P, Abraham P, Sridharan G, et al. Distribution of hepatitis $\mathrm{B}$ virus genotypes in blood donors and chronically infected patients in a tertiary care hospital in southern India. Clin Infect Dis 2004;8:81-6.

14. Asif N, Kokhar N, Ilahi F. Seroprevalence of HBC, HCV and HIV infection among voluntary non-remunerated and replacement donors in northern Pakistan. Pak J Med Sci 2004;1:24-8.

15. Mujeeb SA, Mehmood K. Prevalence of HBV, HCV and HIV infections among family blood donors. Ann Saudi Med 1996;16:702-3.

16. Chandra T, Kumar A, Gupta A. Prevalence of transfusion transmitted infections in blood donors: an Indian experience. Trop Doct 2009;39:152-4.

17. Jain R, GuptaG. Family/friend donors are not true voluntary donors, Asian J Transfus Sci 2012;6:29-31.

18. Lindh M, Horal P, Dhilon AP, et al Hepatitis B virus levels, pre-core mutations, genotypes and histological activity in chronic hepatitis B. J Viral Hepat 2000;7:258-67.

19. Busch MP. Should HBV DNA NAT replace HBsAg and /or anti-HBc screening of blood donors? Transfus Clin Biol 2004;11:26-32.

20. Mine H, Emura H, Miyamoto M. High throughtout screening of 16 million serologically negative blood donors for hepatitis B virus, hepatitis $\mathrm{C}$ virus and HIV type-1 by NAT with specific and sensitive multiplex reagent in Japan. J Virol Methods 2003;112:145-51.

21. Panigrahi AK, Panda SK, Dixit RK, et al. Magnitude of hepatitis $\mathrm{C}$ virus infection in India: Prevalance in healthy blood donors, acute and chronic liver disease. J Med Virol 1997;51:167-74. 